DOI: https://dx.doi.org/10.24093/awej/vol12no3.29

\title{
Mastering Prepositions in English: Explicit versus Implicit Instruction
}

\author{
Rafe S. Zaabalawi \\ Department of Literature and Linguistics \\ College of Arts and Sciences \\ Gulf University for Science and Technology \\ Kuwait \\ Email: rafezaabalawi@hotmail.com
}

Received: 4/28/2021

Accepted: 9/16/2021

Published: 9/26/2021

\begin{abstract}
Prepositions form a hurdle for several EFL learners, Arabs in particular. One major catalyst is that the preposition systems in English and Arabic rarely correspond to one another. Most scholars who researched this area concentrated on the problem itself, rather than finding a successful remedy that can empower these students to masterfully handle such a thorny area. This study is novel inasmuch as it concerns itself with finding means of facilitating this language area for Arab learners. It reveals the effectiveness of using translation to teach English prepositions to these learners. The research question of this study is: do students who have received explicit tuition and adequate practice on the use of English prepositions in translated texts naturally perform better using such grammatical items in subsequently translated texts than those who have not been instructed on such exemplars in similar language contexts? Sixty students at the Gulf University for Science and Technology in Kuwait participated in the field experiment. The study paradigm had a pre-test/post-test protocol. While the pre-test included four fill-in-the-gap exercises, the post-test contained three Arabic passages which participants were required to translate into English. The findings showed that teaching prepositions explicitly in translated texts is a viable technique for EFL learners' mastery of such grammatical items. This has implications for EFL specialists and syllabus designers.

Keywords: Experimental and control groups, explicit tuition, language transfer, prepositions, translation

Cite as: Zaabalawi, R.S. (2021). Mastering Prepositions in English: Explicit versus Implicit Instruction . Arab World English Journal, 12 (3) 411- 431.

DOI: https://dx.doi.org/10.24093/awej/vol12no3.29
\end{abstract}




\section{Introduction}

Prepositions are words that frequently occur in English discourse usually to refer to a point in place or time (e.g., He arrived in Kuwait on Monday). More technically, Yates (1999) defines a preposition as a word used before a noun or a pronoun to show its connection with another lexical item in the same sentence. According to Hornby (2015), a preposition can contain a word or more. To him, a preposition is "a word or a group of words, such as in, from, to, out of and on behalf of, used before a noun or a pronoun to show place, position, time or method" (p. 1154).

Fromkin, Rodman, and Hyams (2018) refer to prepositions as function words (articles, pronouns, conjunctions, auxiliaries, and prepositions) as opposed to what they label content words (nouns, verbs, adjectives, and adverbs). Unlike content words which contain the principal meaning of an utterance, hence the name, function words do not convey much meaning. Although prepositions are considered function words and are, therefore, usually unstressed in English discourse (Hendricks, 2010), any mistake made in their use by EFL learners would meet with disapproval from native English speakers (Zaabalawi \& Gould, 2017). Hendricks (2010) advises teachers to alert their students to this particular language area and emphasizes that mastering it helps learners convey their meanings properly in various English exchanges. She remarks that "since prepositions are so indispensable to communication, and their misuse often distorts meaning, the requirement for correct prepositional usage is essential, especially when writing or speaking in academic contexts or describing abstract relations in more formal contexts" (p. 26).

Arab learners specifically find difficulty using these words in everyday discourse as such words do not normally correspond to those deemed equivalent in Arabic (Celce-Murcia, 2002; Kharma \& Hajjaj, 1997; Swan \& Smith, 2010). For example, while the preposition ?ila ${ }^{l}$ (to) is used in Arabic with verb yaSilu (arrive), this preposition is covered by the preposition in or at in English where someone is said to arrive in Kuwait and at the station rather than to Kuwait and to the station. Moreover, in a prepositional phrase such as on Monday, several Arab learners replace the preposition on with in (fii) since this is the preposition normally used in Arabic in similar language contexts. They find it even more challenging when a preposition is used in Arabic in a language context where no English equivalent exists. For instance, while the Arabic verb yudaafi? (defend) is used with the preposition ?an (about), no such preposition occurs with the verb defend in English; someone is said to defend his rights, rather than defend about his rights.

Improving the competence of Arab learners in using English prepositions is not necessarily a straightforward matter. Instructing these students in the use of English prepositions explicitly in contextualized, translated texts is perhaps a successful methodology. Such a methodology may grant students the ability to understand the differences between the uses of the two preposition systems (Arabic and English) and, in turn, assist them in gaining a good knowledge of such grammatical items. In this study, the researcher seeks to test the value of this methodological 
hypothesis. If this methodology proves to be effective, the study will provide guidance to language practitioners on how to best address this language area, which serves as the rationale for the study. The research question is: do students who have received explicit tuition and adequate practice on the use of English prepositions in translated texts naturally perform better using such grammatical items in subsequently translated texts than those who have not been instructed on such exemplars in similar language contexts? By attempting to answer this question, the researcher seeks to achieve the research objectives which are first, to assist learners in improving their understanding of how the prepositional system operates in English and how they can best use it in their daily language communication; and second, to advise language teachers on how to effectively design their teaching materials when it comes to teaching this specific language area.

Sixty 19-22-year-old students in the Department of Literature and Linguistics at Gulf University for Science and Technology in Kuwait participated in the field experiment. The paradigm had a pre-test/post-test protocol. The sixty participants were divided into two groups: an experimental group and a control group, each consisting of 30 students. The students attended a translation course composed of 48 tuition hours and extending over a 16-week semester (see Methodology section). The findings of the study show that EFL learners' exposure to extensive explicit tuition of English prepositions in translated texts significantly improves their proficiency in English prepositional usage.

The current article consists of five sections. The first, Literature Review, sheds light on several studies that address the advantages of learning English prepositions through translation and the difficulties which Arab learners usually encounter in learning how to use prepositions proficiently in English discourse. The second, Method, introduces the study participants, instruments, and procedures and describes the setting in which the research data were collected. The third, Results, presents the findings of the study in light of the improvement which the study participants achieved in mastering English prepositions. The fourth, Discussion, elaborates on these findings and relates them to those reported in other studies which share similar pedagogical objectives. The fifth, Conclusion, summarises the findings of the research and highlights EFL teachers' role in teaching English prepositions. The sixth, Recommendations, offers advise on how to best teach this language topic, and proposes some future agendas for EFL researchers.

\section{Literature Review}

Teaching grammar through translation has long been a controversial issue (Brown, 2000). It has been frowned upon by several EFL experts who strongly believe that it impedes the L2 learning process inasmuch as it encourages language transfer ${ }^{2}$ and creates in the mind of the L2 learner the inaccurate belief that structural and lexical items correspond tidily across different languages (Kobayashi \& Rinnert 1992; Marsh, 1987; Newson, 1988; Richards \& Rodgers, 1986; Wen \& Johnson, 1997). 
Despite this common conception, towards the end of the twentieth century and the beginning of the twenty-first century, several EFL scholars began viewing teaching grammar through translation as advantageous, particularly at the intermediate, post-intermediate, and advanced stages of learning (Carreres, 2006; Cook, 2001; Hervey, Higgins \& Haywood, 2002; Liao, 2006; Malmkjaer, 1998; Perkins, 1985; Shiyab \& Abdullateef; 2001). In support of this pedagogical concept, Corder (1981), for example, regarded learners' native language as a rich linguistic source to which they can resort to acquire a foreign language. He replaced the term first language "interference" with first language "intercession" to show the favourable role played by L1 in promoting L2 learning. Similarly, Liao (2006) highlighted the significance of L1 in facilitating the mastery of L2 when he maintained that "the use of translation could be a valuable resource or tool that can contribute to the development of various language skills" (p. 210). In this regard, Leonardi (2010) also considered translation a beneficial means of learning a foreign language. She lamented the attitudes adopted by several language specialists, who believe that teaching a foreign language through translation is counterproductive. She pointed out that "Translation is no longer seen as a harmful tool in language learning and its interference tends to be positively evaluated as a way to enrich rather than harm learners' competence and performance" (p. 18). Likewise, Shiyab and Abdullateef (2001) advocated teaching English through translation and emphasized that it does not encourage L1 transfer. Rather, it fosters conscious learning and helps EFL learners better understand the differences between the two languages, which, in turn, aids these learners in developing a better command of their L2. The findings of this study, which concentrates on the positive learning outcomes of teaching English prepositions through ArabicEnglish translation, support this pedagogical principle.

Prepositions in English are notoriously difficult to master for EFL learners (Coleman, 2003; Gvarishvili, 2012; Koruti, 2012; Mueller, 2011; Sanjaya \& Bram, 2021; Swan, 2017). This can be attributed to two main linguistic factors (Alotaibi, Wu, \& Alrabah, 2018). The first pertains to the chaotic nature of the English preposition system itself (Sotiloye, 2010). For instance, although verbs such as arrive and reach are listed in several thesaurus dictionaries as synonyms, arrive generally occurs with a preposition (e.g., in, at) when reach does not, in a given context. Thus, while someone is said to arrive in London or at the station, he/she is said to reach London or the station. Another inconsistency is manifested in the use of prepositions with verbs such as accuse and charge, both of which are typically classified as synonyms. While someone is said to be accused of committing murder, he/she is said to be charged with committing murder. A further example is illustrated using verbs such as conform, abide, comply and follow, all of which are also commonly found in thesaurus dictionaries as synonyms. Whereas someone is said to conform to the rules, he/she abides by, complies with, or follows the rules.

The second linguistic factor which makes competence in English prepositional usage particularly elusive for EFL learners is the fact that they often unconsciously transfer particular prepositions used in their respective native languages into English (Alwreikat \& Yunus, 2020; 
Daquila, 2021; Haddad, 2018; Murshidi, 2014; Nghi, Thang \& Phuc, 2021). As previously mentioned, prepositions do not necessarily correspond to one another across languages (Hendricks, 2010). Swan (2017), for example, states that "Most prepositions have several different functions (. . ) and these may correspond to several different prepositions in another language" (p. 425). Arab learners, for instance, may use inaccurate prepositions that they literally translate from Arabic into English. As a result, they sometimes produce erroneous combinations such as afraid from, responsible from, and angry on instead of afraid of, responsible for, and angry with, respectively (Swan \& Smith, 2010, p. 207). Problems are compounded when one language uses a preposition in a specific linguistic context when another does not. Swan (2017) declared that "Often the correct preposition cannot be guessed, (. . .) In some expressions English has no preposition where one may be used in another language; in other expressions the opposite is true" (p. 425). For instance, Arab learners usually use the preposition to with verb reach because the Arabic equivalent verb yaSilu is chiefly used with ?ila (to). Erroneous sentences such as "John reached to London at 6:00" instead of "John reached London at 6:00" are very common among Arab learners. The opposite practice also exists: a preposition may be used in Arabic but not in English. To illustrate, Arab learners of English may produce erroneous sentences such as "I have been waiting him all day" instead of "I have been waiting for him all day" since in Arabic no such preposition is used in a similar context.

Prepositions, thus, constitute a common problem for EFL learners, Arabs in specific. To help these learners overcome this language difficulty, numerous scholars have researched the thorny aspects of this grammatical topic. Tahaineh (2010), for example, conducted a study involving 162 first-, second-, and third-year Jordanian university students with similar English language proficiency. This cohort was tested on the appropriate use of prepositions in composition assignments. Most errors - 58\% of the total number of errors - were classified as interlingual, i.e. those made due to the students' transferring Arabic rules into English. The other $42 \%$ constituted intralingual errors, i.e. those made due to the students' overgeneralizing preposition rules in English itself (for more on interlingual and intralingual errors see Ellis, 1997; Richards \& Schmidt, 2002; Richards, 2015). Tahaineh (2010) noted that most errors were made in cases where no equivalent prepositions are typically used in English. It is noteworthy that a significant number of these errors were made by advanced students.

In another study, Alotaibi, Wu, and Alrabah (2018) tested 80 tertiary students at the Public Authority for Applied Education and Training in Kuwait on their use of 16 simple prepositions (e.g., on, in, at) and 10 complex prepositions (e.g., prior to, close to). All participants had received their middle school and secondary school education at Kuwaiti public schools. The test included an exercise made up of 26 multiple-choice questions. The findings showed that almost $53 \%$ of these students had more difficulty with the use of prepositions than expected. They made both interlingual and intralingual errors. 
In a similar study, Murshidi (2014) conducted an analysis of preposition errors made by 30 Arab students in the College of Engineering at the United Arab Emirates University. She devised a written test consisting of 30 multiple-choice questions. For each question, students were given three prepositions and were asked to provide the appropriate preposition in the assigned gap. Murshidi found that a high percentage of these errors were made due to L1 interference, particularly in contexts where the preposition used in Arabic does not correspond to that normally assumed to be equivalent in English.

In a similar context, Fareh and Saeed (2009) carried out a study where 50 students at the University of Sharjah were given a set of questions presented in the form of two tasks: a production task and a recognition task. The researchers aimed to evaluate their students' performance in producing and recognizing some of the most frequently used prepositions in English discourse. In the production task, the students were given 40 multiple-choice questions and were required to select the most suitable preposition from a given list. As for the recognition task, it included another 40 multiple-choice questions where the students were asked to circle the correct preposition. In general, students performed poorly in both producing and recognizing the appropriate preposition, though they were generally better at recognizing than producing prepositions.

In another study involving a 12-item questionnaire completed by 40 second-year students at the University of Al Imam Al Mahdi, Al Mubarak (2017) explored the problems faced by these learners in the use of English prepositions. He stated that most difficulties encountered were concerned with the students' lack of exposure to any language communication with native English speakers. Moreover, the respondents complained about the inexistence of a wellorganized grammar syllabus that is designed to teach them such a problematic topic. They also complained that English prepositions have multiple meanings and, thus, referred to them as "highly polysemous", a factor which, they claimed, had caused them even more confusion.

Haddad (2018) administered a multiple-choice test consisting of 20 sentences to a cohort of 50 female students at two Jordanian universities. They were required to select one of the given prepositions or none at all to fill in the gaps provided. In her error analysis, Haddad discussed three different types of preposition errors: (1) errors made when the same preposition is used in both Arabic and English, (2) errors made when a different preposition is used in each language, and (3) errors made when one language uses a preposition while the other does not. Of these three types of errors, the last constituted the highest percentage of errors made by her study participants. Haddad attributed a major part of these errors to language transfer and criticized the teaching strategies employed in the Jordanian language curricula in various educational institutions as pedagogically inadequate. 
Chek, Akkakoson, Odacioglu, Suki, and Bating (2017) conducted another analysis of preposition errors made by 150 sixteen-year-old students in Malaysia. The research instrument consisted of a 350-word composition and a fill-in-the-gap exercise. Most of the errors, which totalled 1457 combined, occurred in the use of prepositions of time and place. The majority of these errors were classified as interlingual rather than intralingual. At the end of their study, Chek et al. (2017) offered advice on some pedagogical strategies on how to best teach English prepositions to ESL learners.

Another analysis of preposition errors was carried out by Ozisik (2014). It involved 30 EFL university students in Turkey who were administered a test comprising 60 sentences of the fillin-the-gap format. Students who were rated upper intermediate were requested to provide the correct preposition from memory or use none at all. Of the 1800 prepositional uses produced by the students, 852 were inaccurate. Nearly half of these errors were found to be intralingual and the other half interlingual made due to the students' Turkish language interference in English. Ozisik concluded that using prepositions in English is problematic for Turkish students, who, he suggested, need to intensively practice this grammatical concept. He proposed a set of strategies on how to best teach prepositions to Turkish students.

One particularly interesting research study on the use of prepositions by EFL learners was carried out by Mahmoud (2011). He conducted an analysis of 50 preposition errors in compositions produced by 50 male and female second-year university students in Oman. Contrary to all the findings reported by the aforementioned studies, he found that his students made mistakes with only less than $20 \%$ of the prepositions they used in their compositions. Thus, unlike most other EFL researchers who consider prepositions a difficult concept for EFL learners to grasp, Mahmoud concluded that English prepositions are generally not hard to master for EFL learners. However, he reported that more than a third of his students' errors were interlingual.

In a similar context, Altakhaineh and Ibrahim (2019) carried out a study in which they tested 50 native Arabic students at Al Ain University of Science and Technology on the use of English prepositions. The participants were divided into two groups, a control group and an experimental group, each consisting of 25 students. The researchers' aim was to assess the efficacy of incidental learning of prepositions in reading texts. The experiment had a pre-test/post-test design where students were specifically tested on their receptive and productive knowledge of prepositions in multiple-choice and fill-in-the-gap exercises. Along with general English exercises, the experimental group received training in reading comprehension passages designed to enhance their reading skills in general. No particular attempt was made to give these students any special training on the use of prepositions. The purpose of this was to ensure that any improvement in the use of prepositions was achieved through incidental learning. The control group, on the other hand, received no such training in reading passages; they were only taught through general English exercises. At the end of the study, the researchers found that the 
experimental group performed much better than the control group. They concluded, therefore, that the mastery of prepositions can be better achieved through incidental learning.

In a unique study, Daquila (2021) sought to explore whether highly-educated students who had a special liking for music would perform better in the use of English prepositions than their similarly educated counterparts. He divided his 29-38 year-old participants into two groups, an experimental group and a control group, each consisting of 20 male and female graduates. While the experimental group, comprising those interested in music, received their instruction on the use of prepositions through music-related exercises, the control group, those uninterested in music, received their instruction through traditional language drills. Interestingly, he found that the former group performed much better in the use of prepositions than the latter. He concluded that "musically intelligent people" generally have a better grasp of the use of prepositions than others (p. 1).

At this stage, it is worthwhile noting that the rules of prepositional usage in English constitute a serious problem not only for EFL learners, who often spend a substantial part of their learning struggling to internalize such rules, but also for several EFL teachers who have considered it a challenging topic to teach. In support of this view, Saravanan (2015) maintains that "prepositions pose a challenge to the learners as well as teachers of English because of the uniqueness of the problem involved" (p. 159). In this connection, Koruti (2014) conducted a study on 50 EFL teachers from Kosovo, Greece, and Albania randomly selected from 300 EFL professionals belonging to the English Language Teachers Association in Albania. He aimed to find out how these teachers taught prepositions to their students, who were at varying English language proficiency levels. Surprisingly, Koruti found, by means of a questionnaire completed by these teachers, that only some of them taught their students prepositions; many of them did not due to the difficulty, they professed, of teaching such a grammar concept. Their students, as a result, had an impoverished understanding of prepositional usage and most of their errors were found to be interlingual.

\section{Method}

\section{Participants}

The study participants were sixty 19-22-year-old Kuwaiti university students in the Department of Literature and Linguistics at Gulf University for Science and Technology, a private university in Kuwait. They were all at the same level of English language proficiency (upper-intermediate) and were all native Arabic speakers.

\section{Instruments}

The research paradigm included a pre-test, taken at the beginning of an Arabic-English translation course, and a post-test, taken at the end of it. The pre-test, set in the form of a cloze test, contained four exercises ${ }^{3}$, each comprising 15 gapped sentences which the students were requested to complete by choosing the appropriate preposition from a given list (Appendix B: 
Pre-test exercises). The post-test, on the other hand, included three Arabic texts ${ }^{4}$ which participants were invited to translate into English over three tuition hours at the end of the course (Appendix C: Post-test translation texts). The assigned texts were carefully selected to contain as many prepositional structures as possible and were on various subjects. The objective was to measure the participants' progress in English prepositional usage by the end of the course.

\section{Procedures}

The course offered consisted of 48 tuition hours distributed over one semester, that is, 16 weeks, three hours per week. During the semester, the participants were requested to translate one Arabic text into English in each class session. By the end of the semester, the students had rendered 45 different Arabic texts into English. Each tuition hour was divided into two approximately equal sessions. During the first session, students were engaged in translating the assigned text while consulting several dictionaries and other reference books that they were advised to use. During the second session, the researcher, who was the course instructor, randomly selected three of the students' translated texts, presented them on the projector, and invited students to make comments on any errors found. In the end, the instructor provided his feedback on these errors and any other errors that the students missed. Consequently, besides being involved in translating 45 texts throughout the course, students had the opportunity to revise, with the aid of their instructor, 135 translation versions produced.

In the field experiment, the sixty students were divided into two 30-student groups: an experimental group and a control group. To eliminate external factors such as contextual learning and developmental changes, experimental and control conditions were created for reliable results (Sekaran \& Bougie, 2013). As the students worked on the translation of each of the 45 Arabic texts, those in the experimental group were partly trained in general translation skills but were particularly exposed to extensive tuition and adequate practice in the grammatical use of the prepositions they produced, whether correct or incorrect, in their newly-written English texts. Students in the control group, on the other hand, were only engaged in translating the Arabic texts and concentrating on Arabic-English rendering skills. Preposition rules were not taught and the whole grammar topic was generally treated as unworthy of mention. The objective was to find out whether students who have received explicit tuition and adequate practice on the use of English prepositions in translated texts naturally perform better using such grammatical items in subsequently translated texts than those who have not been instructed on such exemplars in similar language contexts.

\section{Results}

The findings of the study field experiment are posted in the three tables ${ }^{5}$ below. As stated in the methodology, the study paradigm contains two tests: a pre-test and a post-test. In the pre-test, participants were given sixty different sentences in the form of a cloze test and were requested to complete each gap with the appropriate preposition. Both groups, experimental and control, took 
the same test. As shown in Table one below, out of a total of 1800 prepositional uses, the control group made 810 errors, whereas the experimental group made 793 errors. It is clear from these figures that the experimental group's knowledge of English prepositional usage was similar to that of the control group at the beginning of the field experiment ( $p$-value $=0.569$ ).

Table 1. Pre-intervention proportion of errors made by the experimental and control groups in the cloze test containing prepositions

\begin{tabular}{|l|l|l|l|l|l|l|c|}
\hline & \multicolumn{3}{|c|}{ Control Group's Pre-test } & \multicolumn{2}{c|}{ Experimental Group's Pre-test } & P-value \\
\hline $\begin{array}{l}\text { Number of } \\
\text { Prepositional } \\
\text { Uses }\end{array}$ & $\begin{array}{l}\text { Number } \\
\text { of Errors }\end{array}$ & $\begin{array}{l}\text { Proportion of } \\
\text { Errors }\end{array}$ & $\begin{array}{l}\text { Number of } \\
\text { Prepositional } \\
\text { Uses }\end{array}$ & $\begin{array}{l}\text { Number } \\
\text { of Errors }\end{array}$ & $\begin{array}{l}\text { Proportion of } \\
\text { Errors }\end{array}$ & \\
\hline $\begin{array}{l}\text { Cloze } \\
\text { Test }\end{array}$ & 1800 & 810 & 0.45 & 1800 & 793 & 0.44 & 0.569 \\
\hline
\end{tabular}

In the post-test, however, there was a noticeable difference between the performance of the experimental group and that of the control group. The figures in Table two below highlight the progress which the experimental group achieved in their knowledge of English prepositional usage compared with that made by the control group. In translating the first Arabic text, while the experimental group made only 45 errors out of 503 prepositional uses, the control group made 226 errors out of 524 prepositional uses. As for the second Arabic text, whereas the experimental group made 31 errors out of 390 prepositional uses, the control group made 177 errors out of 422 prepositional uses. Finally, concerning the third Arabic text, while the experimental group made just 30 errors out of 301 prepositional uses, the control group made 126 errors out of 333 prepositional uses. In total, the experimental group made a meagre 104 errors out of 1194 prepositional uses, whereas the control group made 501 errors out of 1279 prepositional uses. These figures reveal that there is a significant difference between the performances of the two groups in English prepositional usage in the three translated Arabic texts ( $p$-value $=0.000)$. A resounding "yes" answers the research question: do students who have received explicit tuition and adequate practice on the use of English prepositions in translated texts naturally perform better using such grammatical items in subsequently translated texts than those who have not been instructed on such exemplars in similar language contexts?

Table 2. Post-intervention proportion of errors made by the experimental and control groups in the three translated texts containing prepositions

\begin{tabular}{|l|l|l|l|l|l|l|l|}
\hline Texts & \multicolumn{3}{|c|}{ Control Group's Post-test } & \multicolumn{3}{|c|}{ Experimental Group's Post-test } & P-value \\
\hline & $\begin{array}{l}\text { Number of } \\
\text { Prepositional } \\
\text { Uses }\end{array}$ & $\begin{array}{l}\text { Number } \\
\text { of Errors }\end{array}$ & $\begin{array}{l}\text { Proportion of } \\
\text { Errors }\end{array}$ & $\begin{array}{l}\text { Number of } \\
\text { Prepositional } \\
\text { Uses }\end{array}$ & $\begin{array}{l}\text { Number } \\
\text { of Errors }\end{array}$ & $\begin{array}{l}\text { Proportion of } \\
\text { Errors }\end{array}$ & \\
\hline $\begin{array}{l}\text { Text } \\
\text { One }\end{array}$ & 524 & 226 & 0.43 & 503 & 45 & 0.09 & $0.000^{*}$ \\
\hline $\begin{array}{l}\text { Text } \\
\text { Two }\end{array}$ & 422 & 177 & 0.42 & 390 & 31 & 0.08 & $0.000^{*}$ \\
\hline $\begin{array}{l}\text { Text } \\
\text { Three }\end{array}$ & 333 & 126 & 0.38 & 301 & 30 & 0.10 & $0.000^{*}$ \\
\hline Total & 1279 & 501 & 0.41 & 1194 & 104 & 0.09 & $0.000^{*}$ \\
\hline
\end{tabular}

- The difference is significant at $\alpha<0.05$. 
In summary, at the end of the Arabic-English translation course, and as is clear from Table three below, the experimental group's performance in English prepositional usage improved by 35\%, compared with that of the control group, who achieved a mere $4 \%$ improvement. This indicates a significant difference between the performances of the two groups in English prepositional usage ( $\mathrm{p}$-values $=0.000,0.001$, respectively).

Table 3. Pre-intervention and post-intervention proportion of prepositional errors made by the experimental and control groups and their rates of error improvement

\begin{tabular}{|l|l|l|l|l|l|}
\hline \multicolumn{3}{|c|}{ Control Group } & \multicolumn{3}{c|}{ Experimental Group } \\
\hline \multicolumn{1}{|c|}{ Pre-test } & \multicolumn{1}{|c|}{ Post-test } & & \multicolumn{1}{c|}{ Pre-test } & \multicolumn{1}{c|}{ Post-test } & \\
\hline $\begin{array}{l}\text { Proportion of } \\
\text { Errositional }\end{array}$ & $\begin{array}{l}\text { Proportion of } \\
\text { Prepositional } \\
\text { Errors }\end{array}$ & $\begin{array}{l}\text { Rate of Error } \\
\text { Improvement }\end{array}$ & $\begin{array}{l}\text { Proportion of } \\
\text { Prepositional } \\
\text { Errors }\end{array}$ & $\begin{array}{l}\text { Proportion of } \\
\text { Prepositional } \\
\text { Errors }\end{array}$ & $\begin{array}{l}\text { Rate of Error } \\
\text { Improvement }\end{array}$ \\
\hline 0.45 & 0.41 & 0.04 & 0.44 & 0.09 & 0.35 \\
\hline P-value & & P-value & & \\
\hline $0.001 *$ & & $0.000 *$ & & \\
\hline
\end{tabular}

- Difference is significant at $\alpha<0.05$.

\section{Discussion}

As can be seen from the study's findings in the Results section, a positive answer is provided to the research question: do students who have received explicit tuition and adequate practice on the use of English prepositions in translated texts naturally perform better using such grammatical items in subsequently translated texts than those who have not been instructed on such exemplars in similar language contexts? The field experiment has, therefore, shown that teaching students explicitly how to use English prepositions in newly-composed texts is a successful technique that can be of interest to pedagogues seeking an effective methodology.

This study is original inasmuch as no other research seems to have concerned itself with teaching English prepositions explicitly in translated texts. Moreover, no similar studies have provided evidence that teaching such exemplars in similar language contexts has a special utility in improving EFL learners' knowledge of using prepositional formations in English discourse. Leonardi (2010) emphasizes the vital role of translation in teaching EFL learners the grammar of the target language. In her book "The Role of Pedagogical Translation in Second Language Learning", she observes that:

there is a strong relationship between translation and foreign language teaching (...) The use of translation in language classes is (. . .) a means to help learners acquire, develop and further strengthen their knowledge and competence in a foreign language. (p. 17)

This is because, through translation, EFL learners can better identify the similarities and differences between the two languages, which can, in turn, enable them to manipulate the foreign language rules more proficiently (Malmkjaer, 1998; Shiyab \& Abdullateef, 2001). Moreover, Leonardi (2010) reiterates that, through translation, "students have the opportunity to see and evaluate similarities and differences between different writing styles in different languages" ( $p$. 
24). All these arguments highlight the instrumental role of translation in teaching English grammar.

\section{Conclusion}

As stated in the Literature Review, there is a consensus among several language specialists that prepositions are one grammatical concept which EFL learners are required to master if they are to acquire native-like fluency in English. Several EFL learners, particularly Arabs who are at the initial stages of their language apprenticeship, experience many difficulties trying to master this language area. They fail to realize that prepositions across languages do not necessarily correspond to one another and, consequently, often pair each Arabic preposition with one which they believe is equivalent in English. As a result, they unconsciously make several preposition errors, which can often hinder effective language communication. To help these learners master this language area, this article has researched the effectiveness of one methodology in teaching prepositions. The research question is: do students who have received explicit tuition and adequate practice on the use of English prepositions in translated texts naturally perform better using such grammatical items in subsequently translated texts than those who have not been instructed on such exemplars in similar language contexts? In response to this question, the field experiment has provided evidence that teaching prepositions explicitly in translated texts is a successful methodology of teaching such grammatical items.

In this regard, English language teachers play a pivotal role in introducing their students to English prepositions by constantly raising their awareness of the function of such language items. Ellis (1997) elaborates on this, noting that it is fundamental for language learners to observe a rule before they can learn it. This observation of rules occurs particularly when such rules are taught through translation where differences between the two languages are easily identified. In such language contexts, teachers can provide their students with explicit, detailed instruction on how to use prepositions appropriately in English.

\section{Recommendations}

To eliminate the active involvement of several EFL learners in translating English prepositions literally and facilitate the acquisition process for them, teachers should encourage these students to learn prepositions in combination with lexical items rather than as individual language items. Lexical items such as nouns, verbs, adjectives, and adverbs should be retained along with the prepositions they normally occur with as whole blocks. For instance, EFL learners should learn solution to, and not solution + to, comply with, and not comply + with, keen on, and not keen + on, and independently of, and not independently + of (Chek, et al., 2017; Ellis, 2003; Ozisik, 2014). This way, students acquire a good command of English prepositions and use them more naturally and appropriately in English discourse. 


\section{Endnotes}

1.The Arabic phonetic symbols used in this article are taken from Campbell's (1998) Arabic transcription chart (Appendix A: Campbell's (1998) chart of Arabic transcription symbols).

2. Language transfer, used in this article, refers specifically to 'negative transfer' as opposed to 'positive transfer'. In this respect, Leonardi (2010) maintains that while negative transfer "occurs whenever first language habits interfere with second language learning causing "interference", positive transfer "occurs when first language habits favour the acquisition of second language habits" (p. 40).

3. These exercises were taken from Azar (2006).

4. The Arabic texts were taken from Abboud and McCarus (2010).

5. In the Results section, the formats of the three tables containing the findings of the field experiment are adapted from Zaabalawi and Gould (2017).

\section{About the author}

Dr. Rafe Zaabalawi earned his $\mathrm{PhD}$ in applied linguistics from the University of East Anglia in the United Kingdom in 1992. As a Fulbright scholar, he conducted post-doctoral research in the United States at Georgetown University in 1999. His area of interest is vocabulary and collocation teaching. Currently, he lectures on translation and vocabulary learning strategies at several universities in the Arabian Gulf region. ORCID ID: https://orcid.org/0000-0002-46640121.

\section{References}

Abboud, P., \& McCarus, E. (Eds.). (2010). Modern Standard Arabic (parts 1 \& 2). Cambridge: Cambridge University Press.

Al Mubarak, A. (2017). The complications of learning and understanding English prepositions among students at Al Imam Al Mahdi University in Sudan. Journal of Language Teaching and Research, 8(5), 871-880. https://doi.org/10.17507/j1tr.0805.05

Alotaibi, A., Wu, S., \& Alrabah, S. (2018). Challenges in learning English prepositions by Kuwaiti EFL learners: A call for bridging the gap in Kuwait's new English language curriculum. Advances in Social Sciences Research Journal, 25, 516-530. https://doi.org/10.14738/assrj.511.5659

Altakhaineh, A. M., \& Ibrahim, M. K. (2019). The incidental acquisition of English prepositions by Arabic-speaking EFL learners: Evidence from Al Ain University of Science and Technology.

SAGE, 9(3), 1-10. https://doi.org/10.1177\%2F2158244019861497

Alwreikat, E. A., \& Yunus, K. B. (2020). Conventional errors in employing English prepositions in the written work of EFL Jordanian students. International Journal od Academic Research in Business \& Social Studies, 10(3), 488-496. https://www.researchgate.net/publication/343674321

Azar, B. S. (2006). Understanding and using English grammar. New York: Pearson.

Brown, H. D. (2000). Principles of language learning and teaching. San Francisco: Longman.

Campbell, S. (1998). Translation into the second language. London and New York: Longman. Carreres, A. (2006, December). Strange bedfellows: Translation and language teaching. The 
teaching of translation into L2 in modern languages degrees: Uses and limitations. In Sixth Symposium on Translation, Terminology and Interpretation in Cuba and Canada. Canadian Translators, Terminologists and Interpreters Council. Retrieved from http://www.cttic.org/publications_06Symposium.asp.

Celce-Murcia, M. (2002). Teaching English as a second or foreign language. New York: Heinle and Heinle.

Chek, K. L., Akkakoson, S., Odacioglu, M., Suki, N., \& Bating, H. (2017). Malay ESL Students' Difficulties in using English prepositions. International Journal of Languages, Literature and Linguistics, 3(3), 122-127. http://dx.doi.org/10.18178/ij1l1.2017.3.3.121

Coleman, S. (2003). English prepositions. Cambridge: CUP.

Cook, V. J. (2001). Using the first language in the classroom. Canadian Modern Language Review, 57(3), 184-206. https://doi.org/10.3138/cmlr

Corder, S. (1981). Error analysis and interlanguage. Oxford: Oxford University Press.

Daquila, J. P. R. (2021). The interference of Arabic prepositions in Emirati English. Multidisciplinary Digital Publishing Institute (MDPI), 3(19), 1-28. https://doi.org/10.3390/sci3020019

Ellis, R. (1997). Second language acquisition. Oxford: Oxford University Press.

Ellis, N.C. (2003). Constructions, chunking and connectionism: The emergence of second language structure. In C. J. Doughty, \& M. H. Long (Eds.), The handbook of second language acquisition (pp. 63-103). Oxford: Blackwell.

Fareh, S., \& Saeed, A. (2009). Problems Arab EFL students encounter in learning prepositions. International Journal of Arabic-English Studies, 10, 93-112.

Fromkin, V., Rodman, R., \& Hyams, N. (2018). An introduction to language. USA: Cengage Learning.

Gvarishvili, Z. (2012). Interference of L1prepositional knowledge in acquiring of prepositional usage in English. Procedia, Elsevier, 1565-1573. http://doi.org/10.1016/j.sbspro.2013.01.224

Haddad, M. (2018). The impact of L1 transfer on the interaction of EFL students with English prepositions. International Forum of Teaching and Studies, 14(2), 20-26.

Hendricks, M. (2010). Consciousness-raising and prepositions. English Teaching Forum, 48 (2), 24-29. https://files.eric.ed.gov/fulltext/EJ914889.pdf

Hervey, S., Higgins, I., \& Haywood, L. (2002). A course in translation method: Spanish to English. London: Routledge.

Hornby, A. S. (2015). Oxford Advanced Learner's Dictionary. Oxford: Oxford University Press.

Kharma , N., \& Hajjaj, A. (1997). Errors among Arabic speakers: Analysis and remedy. Beirut: Libraire du Liban.

Kobayashi, H., \& Rinnert, C. (1992). Effects of first language on second language writing: Translation versus direct composition. Language Learning, 42(2), 183-215. https://doi.org/10.1111/j.1467-1770.1992.tb00707 
Koruti, O. (2012). Difficulties that EFL teachers face while they teach prepositions. Lingua Mobilis, 2(35), 109-123.

Leonardi, V. (2010). The role of pedagogical translation in second language acquisition: From theory to practice. Switzerland: Peter Lang.

Liao, P. (2006). EFL learners' beliefs about and strategy use of translation in English learning. RELC Journal, 37(2), 191-215. https://doi.org/10.1177\%2F0033688206067428

Mahmoud, A. (2011). The use of prepositions by Arab EFL learners: Looking on the bright side. The Buckingham Journal of Language and Linguistics, 4, 84-90.

Malmkjaer, K. (1998). Translation and language teaching. Manchester: St Jerome.

Marsh, H. W. (1987). Students' evaluations of university teaching: Research findings, methodological issues, and directions for future research. Elsevier, International Journal of Educational Research, 11(3), 253-388. https://doi.org/10.1016/0883-0355(87)90001-2

Mueller, C. (2011). English learners' knowledge of prepositions: Collocational knowledge or knowledge-based on meaning? Elsevier, System 39, 480-490. http://dx.doi.org/10.1016/j.system.2011.10.012

Murshidi, G. (2014). The difficulties of UAE university students in the use of prepositions. European Scientific Journal, 10(17), 173-191.

Newson, D. (1988, April). Making the best of a bad job: The teaching and testing of translation. Paper presented at the Annual Meeting of the International Association for Teachers of English as a Foreign Language. Edinburgh, Scotland.

Nghi, T. T., Thang, N. T., \& Phuc, T. H. (2021). An investigation into factors affecting the use of English prepositions by Vietnamese learners of English. International Journal of Higher Education, 10(1), 24-40. https://doi.org/10.5430/ijhe.v10n1p24

Ozisik, C. (2014). Identifying preposition errors of Turkish EFL students. ELT Research Journal, 3(2), 59-69. https://dergipark.org.tr/en/pub/eltrj/issue/5482/74451

Perkins, C. (1985). Sensitizing advanced learners to problems of L1-L2 translation. In C. Titford, \& A. E. Hieke (Eds.), Translation in Foreign Language Teaching and Testing (pp. 5172). Germany: Tubingen.

Richards, J. C., \& Rodgers, T. (1986). Approaches and methods in language teaching. Cambridge: Cambridge University Press.

Richards, J. C., \& Schmidt, R. (2002). Dictionary of Language Teaching and Applied Linguistics (3rd Ed.). London: Longman.

Richards, J. C. (2015). Error analysis: Perspectives on second language acquisition. London: Longman.

Sanjaya, A. A., \& Bram, B. (2021). Investigating preposition usage problems of English language education study program students. SAGA, 2(1), 19-33. http://doi.org/10.21460/saga.2020.21.65

Saravanan, J. (2015). The use of English prepositions: An empirical study. Journal of NELTA, 19(1-2), 158-168. https://doi.org/10.3126/nelta.v19i1-2.12089

Sekaran, U., \& Bougie, R. (2013). Research methods for business. UK: Wiley \& Sons Ltd. Shiyab, S., \& Abdullateef, M. (2001). Translation and foreign language teaching. Journal of 
Arab World English Journal (AWEJ) Volume 12. Number 3. September 2021

Mastering Prepositions in English: Explicit versus Implicit Instruction

Zaabalawi

King Saud University - Languages \& Translation, 13, 1-9.

Swan, M. (2017). Practical English Usage. Oxford: Oxford University Press.

Swan, M., \& Smith, B. (2010). Learner English: A teacher's guide to interference and other problems. Cambridge: Cambridge University Press.

Tahainah Y., S. (2010). Arab EFL University students' errors in the use of prepositions.

The Modern Journal of Applied Linguistics, 2, 76-112.

Wen, G., \& Johnson, R. K. (1997). L2 learner variables and English achievement: A study of tertiary-level English majors in China. Applied Linguistics, 18(1), 27-48. https://doi.org/10.1093/applin/18.1.27

Yates, J. (1999). The ins and outs of prepositions: A guidebook for ESL students. New York: Barron's Educational Series.

Zaabalawi, R. S., \& Gould, A. M. (2017). English collocations: A novel approach to teaching the language's last bastion. Elsevier, Ampersand, 4, 21-29.

http://dx.doi.org/10.1016/j.amper.2017.03.002

\section{Appendix A: Campbell's (1998) Chart of Arabic Transcription Symbols}

\begin{tabular}{|c|c|}
\hline Arabic Consonant & Transcription \\
\hline i & $?$ \\
\hline ب ب & $\mathrm{b}$ \\
\hline ت & $\mathrm{t}$ \\
\hline$\dot{H}$ & $\underline{\mathrm{t}}$ \\
\hline ج & $\mathrm{j}$ \\
\hline$\tau$ & $\mathrm{H}$ \\
\hline$\dot{\tau}$ & $\mathrm{x}$ \\
\hline I & $\mathrm{d}$ \\
\hline$j$ & $\underline{\mathrm{d}}$ \\
\hline J & $\mathrm{r}$ \\
\hline$j$ & $\mathrm{z}$ \\
\hline س & $\mathrm{s}$ \\
\hline ش & $\underline{\mathrm{S}}$ \\
\hline ص & $S$ \\
\hline ض & $\mathrm{D}$ \\
\hline$b$ & $\mathrm{~T}$ \\
\hline ظ & $\mathrm{Z}$ \\
\hline$\varepsilon$ & 3 \\
\hline$\dot{\varepsilon}$ & $\mathrm{g}$ \\
\hline ف & $\mathrm{f}$ \\
\hline ق & $\mathrm{q}$ \\
\hline ك5 & $\mathrm{k}$ \\
\hline J & $\mathrm{L}$ \\
\hline 5 & $\mathrm{m}$ \\
\hline ن ن & $\mathrm{n}$ \\
\hline 0 & $\mathrm{~h}$ \\
\hline
\end{tabular}


Arab World English Journal (AWEJ) Volume 12. Number 3. September 2021

Mastering Prepositions in English: Explicit versus Implicit Instruction

Zaabalawi

\begin{tabular}{|c|c|}
\hline$g$ & w \\
\hline s & y \\
\hline
\end{tabular}

\section{Appendix B: Pre-test Exercises}

\section{EXERCISE 21. Prepositions. (Chart E)}

Directions: Complete the sentences with appropriate prepositions.

1. Do you believe in ghosts?

2. Anthony is engaged my cousin.

3. Ms. Ballas substituted our regular teacher.

4. I can't distinguish one twin the other.

5. Did you forgive him lying to you?

6. Children rely their parents for food and shelter.

7. Tim wore sunglasses to protect his eyes the sun.

8. Chris excels sports.

9. Andrea contributed her ideas the discussion.

10. I hope you succeed your new job.

11. I'm very fond their children.

12. The firefighters rescued many people the burning building.

13. I don't care spaghetti. I'd rather eat something else.

14. Charles doesn't seem to care his bad grades.

15. Sometimes Bobby seems to be jealous his brother.

\section{EXERCISE 22. Prepositions. (Chart E)}

Directions: Complete the sentences with appropriate prepositions.

1. Max is known his honesty.

2. Mr. and Mrs. Jones have always been faithful each other.

3. Do you promise to come? I'm counting you to be here.

4. Trucks are prohibited using residential streets.

5. The little girl is afraid an imaginary bear that lives in her closet.

6. Do you take good care your health?

7. I'm worried this problem.

8. I don't agree you.

9. We decided eight o'clock as the time we should meet.

10. Who did you vote in the last election?

11. How many students were absent class yesterday?

12. It is important to be polite other people.

13. The farmers are hoping rain.

14. Jason was late because he wasn't aware the time.

15. We will fight __ our rights.

15. We will fight __ our rights.

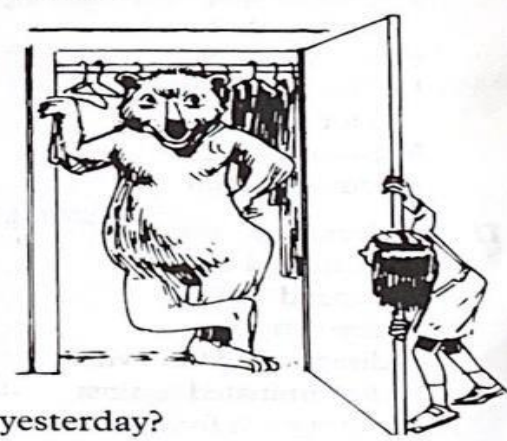


EXERCISE 23. Prepositions. (Chart E)

Directions: Complete the sentences with appropriate prepositions.

1. I am not familiar that author's works.

2. He doesn't approve smoking.

3. I subscribe several magazines.

4. Water consists oxygen and hydrogen.

5. I became uncomfortable because she was staring me.

6. She hid the candy the children.

7. He never argues his wife.

8. I arrived this country two weeks ago.

9. We arrived the airport ten minutes late.

10. Has Mary recovered her illness?

11. I pray peace.

12. I am envious people who can speak three or four languages fluently.

13. Why are you angry me? Did I do something wrong?

14. They are very patient their children.

15. The students responded the questions.

\section{EXERCISE 24. Prepositions. (Chart E)}

Directions: Supply appropriate prepositions.

1. I am grateful you your assistance.

2. The criminal escaped prison.

3. Elizabeth is not content the progress she is making.

4. Paul's comments were not relevant the topic under discussion.

5. Have you decided a date for your wedding yet?

6. My boots are made leather.

7. I'm depending you to finish this work for me.

8. Patricia applied admission the university.

9. Daniel dreamed some of his childhood friends last night.

10. Mr. Miller dreams owning his own business someday.

11. The accused woman was innocent the crime with which she was charged.

12. Ms. Sanders is friendly everyone.

13. Benjamin was proud himself for winning the prize.

14. The secretary provided me a great deal of information.

15. Ivan compared the wedding customs in his country those in the United States. 


\section{Appendix C: Post-test Translation Texts}

\section{Appendix III}

\section{Text One}

طَهَ حُسَبْنْ

كان طهَ حسين من اشثهر ادباء العرب في القرن العثرين واعظم

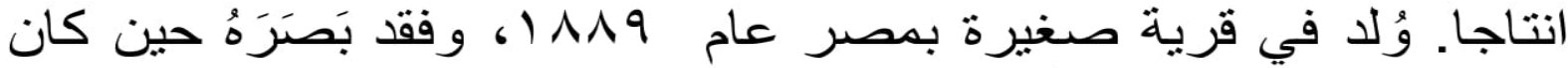
في الثالثة من عمره. تعلّم القرآن في القربة، ودرس في الاز هر، ثم تابع در استه في الجامعة المصرية (التي تعرف ف اليوم بجامعة القاهرة) عَلى كبار

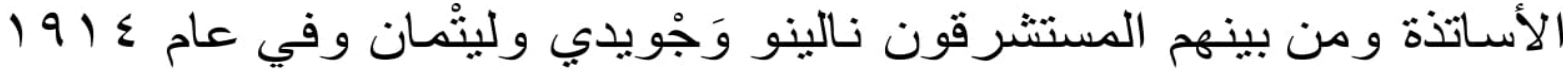
حصل على شـهادة الدكثور اه برسالتهه عن أبي العَلاء المَعَرِي.

بعد ان انهى طه حسين دراسته في مصر ، أرسل الى فرنسا، فدرس

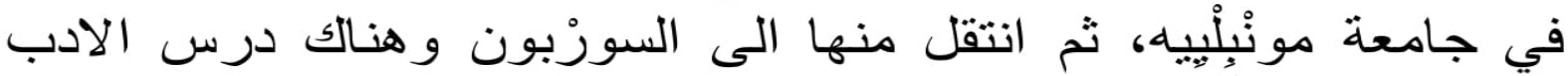
الكِلاسبكي، وتأثّر بـالادب الفرنسي و الثقافة الأوروبية وحصل على شهادة الدكتور اه برسالته عن ابْن خَلْدون. وفي باربس قابل الفتاة التي صسارت له زوجة ولعينيه بَصَرَاً.

و عند رجو عه الى مصر صسار أستاذا للادب العربي في كلّيّة الاداب بالجامعة المصرية، ثم عميداً لهذه الكلّيّة، ثم رئيسا لجامعة الاسكندريّة، وما زال يترقَى حتى صار وزيرا للتربية والتعليم في عام . 90 1، فقتح

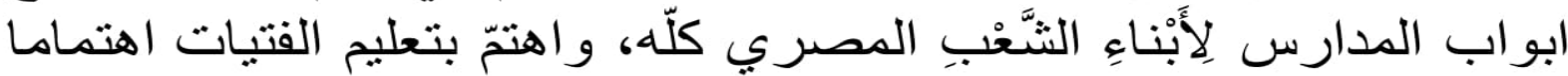

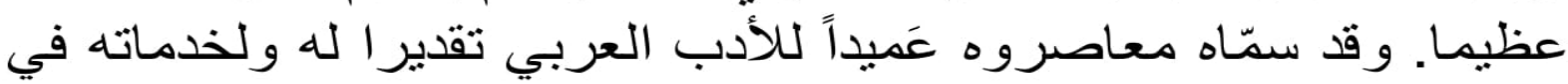
المبادين الأدبية و الثثافية.

كان لانتاجه الكبير تأثير عظيم على النهضة الأدبية في العالم العربي، وسـاعد ذللك الانتاج مساعدة كبيرة على تقدّم الثقافة العربية. ومن اهمّ كثبه "الاَبَّام" و "في الثَعْرِ الجاهِلِيِّ"، و "مستقبل الثقافة في مصر ". 
Text Two

الفصحى و العاميّيّة

العربيّة المستخدمة اليوم في العالم العربيّ تشمل اللغة الفصحى الفيّل و اللهجات العاميّّة. الفصحى هي لغة القرآن وانتاج الادباء العرب من بداية

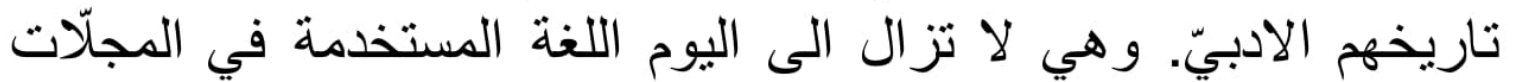

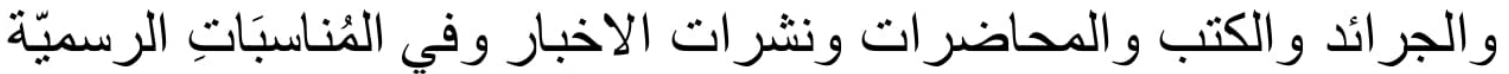

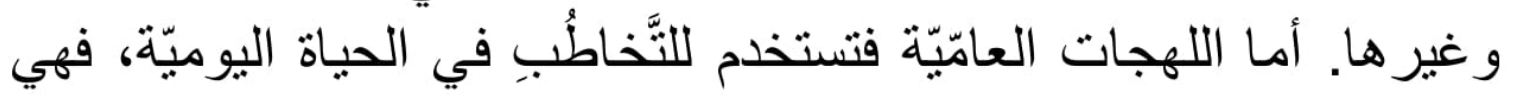
تستخدم مثنلا في البيت و الثار ع.

لقد تطوّرت الفصحى و العامّيّة خلال تاريخهما الطويل تطوّر ا كبير ا.

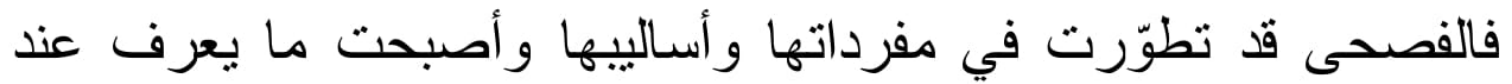

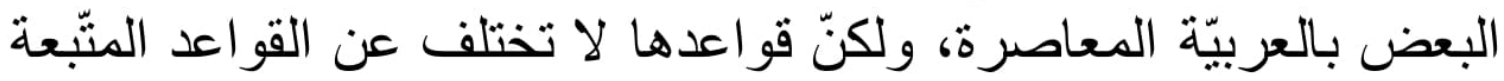

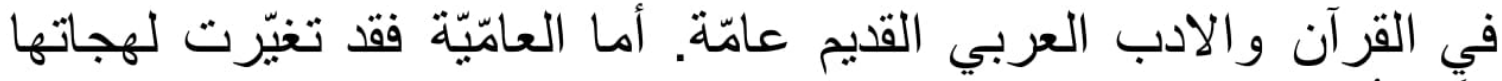

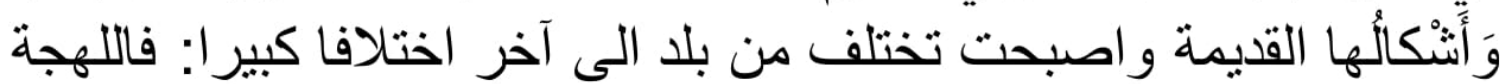

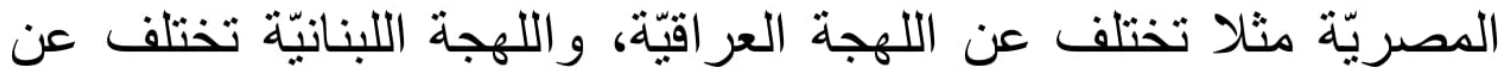
اللهجة التونسيّة، بل ان اللهجات تختلف في الدولة الواحدة فلهجة القاهرة

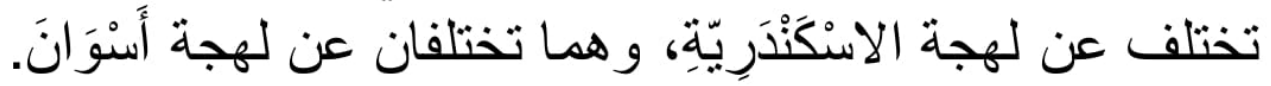

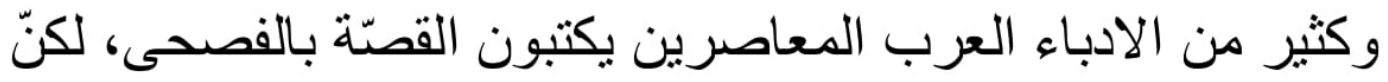
البعض يفضيّلون كتابة الحِوارِ بالعاميّيّة. و ون المنّقق عليه ان اللغة العربية هي الرابطة اللغوية التي تربط بلاد العالم العربيّ المعاصر. 


\section{Text Three \\ منظّمة الأمم المتّحدة}

اجتمعت بعد الحرب العالميّة الثانية بعض الدول الكبرى و عدد من الدول الصغرى في مدينة سان فر انسيسكو واتِققت على تأسيس منظّمة الأمم المتّحدة، ووضعت ميثاقاً لها.

للمنظّمة سكرتير عامُّ، وللاول الأعضاء مندوبون فيها. من أهداف هذه المنظمة المحافظة على السلام العالميّ وحقوق الانسان، ولذلك نجد أنّ معظد شعوب العالم تضع ثقتها الكبيرة فيها وتصفها بأنّها من أهم المنظّمات السياسية.

ونشـاط منظّمة الأمم المتحدة لا يتّمل بالسياسة فقط، فإنّ لها فُروعاً

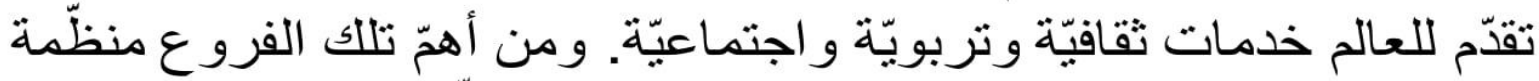

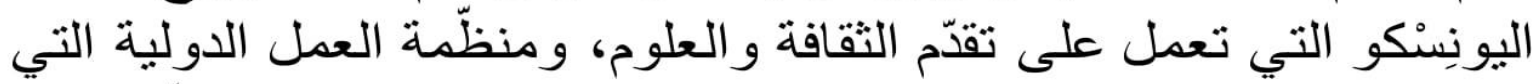

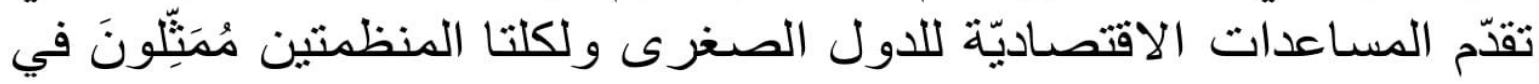
العالم العربيّ.

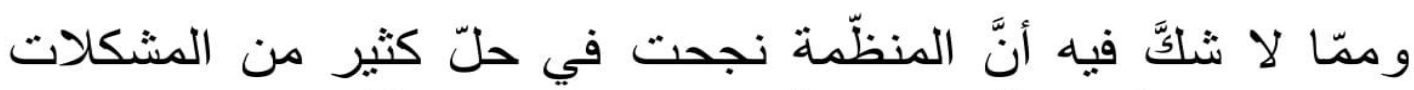

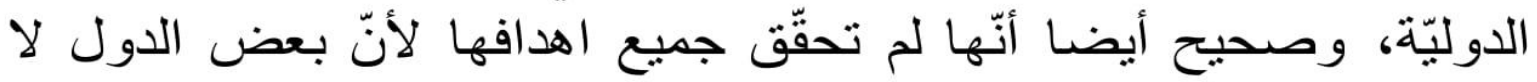
تتعاون معها كلّ التعاون. 